\title{
УДК 332.143
}

https://doi.org/10.32689/2617-2224-

2020-5(25)-53-62

Бурик Зоряна Михайлівна,

доктор наук з державного управління, професор кафедри управління та бізнес-адміністрування Інституту післядипломної освіти та довузівської підготовки Прикарпатського начіонального університету ім. В. Стефаника, 76018, м. Івано-Франківськ, вул. Шевченка, 57, тел.067-999-42-40, e-mail: z.burik@ukr. net, https://orcid.org/0000-0002-43946766

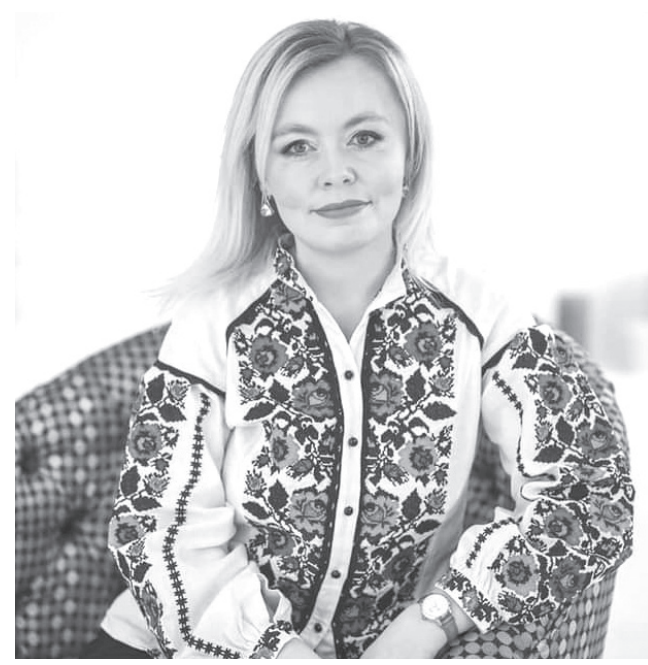

\section{Бурик Зоряна Михайловна,}

доктор наук по государственному управлению, профессор кафедры управления и бизнес-администрирования Института последипломного образования и довузовской подготовки Прикарпатского начионального университета им. В. Стефаника, 76018, г. Ивано-Франковск, ул. Шевченко, 57, тел. 067-999-42-40, e-mail: z.burik@ukr.net, https://orcid.org/0000-0002-4394-6766

\section{Buryk Zoriana Mykhajliona,}

Doctor of science in Public Administration, Professor, Department of Management and Business Administration, Institute of Graduate Studies and Preuniversity Education Vasyl Stefanyk Precarpathian National University 76018, Ivano-Frankivsk, 57 Shevchenko Str., tel.067-999-42-40, e-mail: z.burik@ukr.net, https://orcid.org/0000-0002-4394-6766

\section{СТРАТЕГІЧНЕ ПЛАНУВАННЯ РОЗВИТКУ ТЕРИТОРІЙ, ЯК ІНСТРУМЕНТ УПРАВЛІННЯ}

Анотація. На сьогодні необхідність та актуальність планувальної діяльності на місцевому рівні не викликає сумнівів. В Україні, як й в інших країнах світу, активно розвивається і запроваджується саме стратегічний підхід до планування територіального розвитку. У статті досліджено сутність стратегічного планування розвитку територій як складової системи місцевого управління у контексті децентралізації, регіонального розвитку та становлення інформаційного суспільства. Розглянуто функції стратегічного управління, які реалізуються під час процесу планування, та виконання яких сприяє економічному та соціальному розвитку регіону. Визначено основні принципи стратегічного планування на регіональному рівні, які істотно пришвидшують політичні, економічні, соціальні, технологічні, екологічні та інші зміни розвитку територій. Узагальнено особливості стратегічного планування, які б допомагали відповісти на виклики сучасного глобалізованого 
світу, та доведено значення SMART-спеціалізації в сучасних умовах, визначено важливість досягнення цілей сталого розвитку за допомогою стратегічного планування. Підкреслено, що функції, які виконує планування, видозмінюються, оскільки зазнає суттєвих змін безпосередня роль планування у системі місцевого управління з урахуванням нових цінностей і довгострокових пріоритетів. У статті дано порівняльну характеристику традиційного та стратегічного планування, які враховуються при розробці Планів розвитку територій, та є основою різних підходів до розробки Стратегій їх розвитку. Розглянуто систему цілей стратегічного планування місцевого розвитку в контексті підвищення конкурентоспроможності територій і регіонів, яка поєднує оперативні і стратегічні цілі, пріоритети територіального розвитку в довгостроковій перспективі та підсумки стратегічного бачення розвитку територій.

Ключові слова: регіональний розвиток, децентралізація, управління територіями, інструмент, стратегія розвитку.

\section{СТРАТЕГИЧЕСКОЕ ПЛАНИРОВАНИЕ РАЗВИТИЯ ТЕРРИТОРИЙ КАК ИНСТРУМЕНТ УПРАВЛЕНИЯ}

Аннотация. На сегодня необходимость и актуальность планировочной деятельности на местном уровне не вызывает сомнений. В Украине, как и в других странах мира, активно развивается и внедряется именно стратегический подход к планированию территориального развития. В статье исследована сущность стратегического планирования развития территорий как составляющей системы местного управления в контексте децентрализации, регионального развития и становления информационного общества. Рассмотрены функции стратегического управления, которые реализуются в процессе планирования, и выполнение которых способствует экономическому и социальному развитию региона. Определены основные принципы стратегического планирования на региональном уровне, которые существенно ускоряют политические, экономические, социальные, технологические, экологические и другие изменения развития территорий. Обзор особенности стратегического планирования, которые помогали ответить на вызовы современного глобализирующегося мира, и доказано значение SMART-специализации в современных условиях, определены важность достижения целей устойчивого развития с помощью стратегического планирования. Подчеркнуто, что функции, которые выполняет планирование, видоизменяются, поскольку претерпевает существенные изменения непосредственная роль планирования в системе местного управления с учетом новых ценностей и долгосрочных приоритетов. В статье дана сравнительная характеристика традиционного и стратегического планирования, которые учитываются при разработке планов развития территорий, и является основой различных подходов к разработке стратегий их развития. Рассмотрена система целей стратегического планирования местного развития в контексте повышения конкурентоспособности территорий и регионов, которая сочетает оперативные 
и стратегические цели, приоритеты территориального развития в долгосрочной перспективе и итоги стратегического видения развития территорий.

Ключевые слова: региональное развитие, децентрализация, управление территориями, инструмент, стратегия развития.

\title{
STRATEGIC PLANNING OF TERRITORIAL DEVELOPMENT AS A MANAGEMENT TOOL
}

\begin{abstract}
Today, the need and relevance of planning activities at the local level is beyond doubt. In Ukraine, as in other countries of the world, it is the strategic approach to territorial development planning that is being actively developed and introduced. The article examines the essence of strategic planning of territorial development as a component of local government in the context of decentralization, regional development and the formation of the information society. The functions of strategic management, which are implemented during the planning process and the implementation of which contributes to the economic and social development of the region, are considered. The basic principles of strategic planning at the regional level are identified, which significantly accelerate political, economic, social, technological, environmental and other changes in the development of territories. The peculiarities of strategic planning that would help to meet the challenges of today's globalized world are summarized and the importance of SMART-specialization in modern conditions is proved, the importance of achieving sustainable development goals through strategic planning is determined. It is emphasized that the functions performed by planning are changing, as the direct role of planning in the local government system undergoes significant changes, taking into account new values and long-term priorities. The article gives a comparative description of traditional and strategic planning, which are taken into account in the development of development plans and is the basis of different approaches to the development of strategies for their development. The system of goals of strategic planning of local development in the context of increasing the competitiveness of territories and regions is considered, which combines operational and strategic goals, priorities of territorial development in the long run and the results of the strategic vision of territorial development.
\end{abstract}

Keywords: regional development, decentralization, territorial management, tool, development strategy.

Постановка проблеми. Серед реформ, які проводяться в Україні, важливе значення має адміністративно-територіальна реформа, без проведення якої неможливо забезпечити сталий економічний розвиток окремих регіонів, підвищення їх кон- курентоспроможності і збільшення внеску окремих регіонів у зростання економіки держави. Важливим інструментом управління розвитком територій у сучасних динамічних умовах $€$ стратегічне планування, яке зорієнтоване на загальнодержав- 
ний і регіональний рівень. Реалізація стратегічних рішень значною мірою залежить від регіональної влади та органів місцевого самоврядування. У сучасних умовах набули значного поширення тенденції SMART-спеціалізації регіонального розвитку, інноваційності розвитку територій, стимулювання сталого розвитку. Актуальність тематики дослідження підтверджується у підвищенні значення стратегування на рівні окремих територій, поширенні сучасних тенденцій розробки і реалізації регіональних стратегій.

Аналіз останніх досліджень і публікацій. Вагомий внесок у дослідження теоретичних та методичних аспектів стратегічного планування розвитку територій зробили О. Берданова, М. Бриль, В. Вакуленко, В. Варцаба, О. Врублевський, Д. Зуб, Г. Кіш та ін. Проте, невизначеність окремих питань, пов'язаних 3 організацією стратегічного планування розвитку територій, вимагає подальших теоретичних і практичних розробок у даному напрямі.

Мета статті - дослідження змісту стратегічного планування розвитку регіону як інструмента стратегічного управління, його принципів, базових стратегічних планових документів.

Виклад основного матеріалу. Відповідно до Державної стратегії регіонального розвитку на 20212027 роки від 5 серпня 2020 р. № 695 стратегічне планування є важливим інструментом державного стратегічного управління розвитком регіону, що допомагає підтримувати економічні пропорції і координує роботу всіх ланок економічної системи держави. Разом з тим, у Державній стратегіï регіонального розвитку на 2021-2027 роки зазначено, що певний потенціал стратегічних планів щодо реалізації проектів на регіональному рівні не є головним інструментом регіонального розвитку, а лише однією з його складових [1]. Стратегічне управління розвитком регіону визначається як вид управління, при якому функціонування окремої території, що зорієнтований на цільові вимоги, швидко адаптується до зовнішнього середовища, добирає засоби для підвищення конкурентоспроможності території, що в результаті забезпечує стабільний розвиток у довгостроковій перспективі [2, с. 93] (рис.).

Стратегічне управління територіями виконує п'ять функцій: планування стратегії певної території; організація та виконання сформованого плану дій; координація дій 3 реалізації стратегічних завдань; мотивація для досягнення бажаних стратегічних результатів; контроль за виконанням плану стратегічного розвитку територіï [3, с. 132].

Стратегічне планування, будучи складовою стратегічного управління соціально-економічним розвитком регіону та головною функцію управлінської діяльності органів місцевого самоврядування, направлене на розробку стратегічних рішень, реалізація яких передбачає ефективне функціонування у довгостроковій перспективі певної територіальної громади. Розробка стратегічних рішень передбачає визначення конкретних цілей і стратегії поведінки суб'єктів управління.

Стратегічне планування націлене на прийняття важливих рішень щодо 


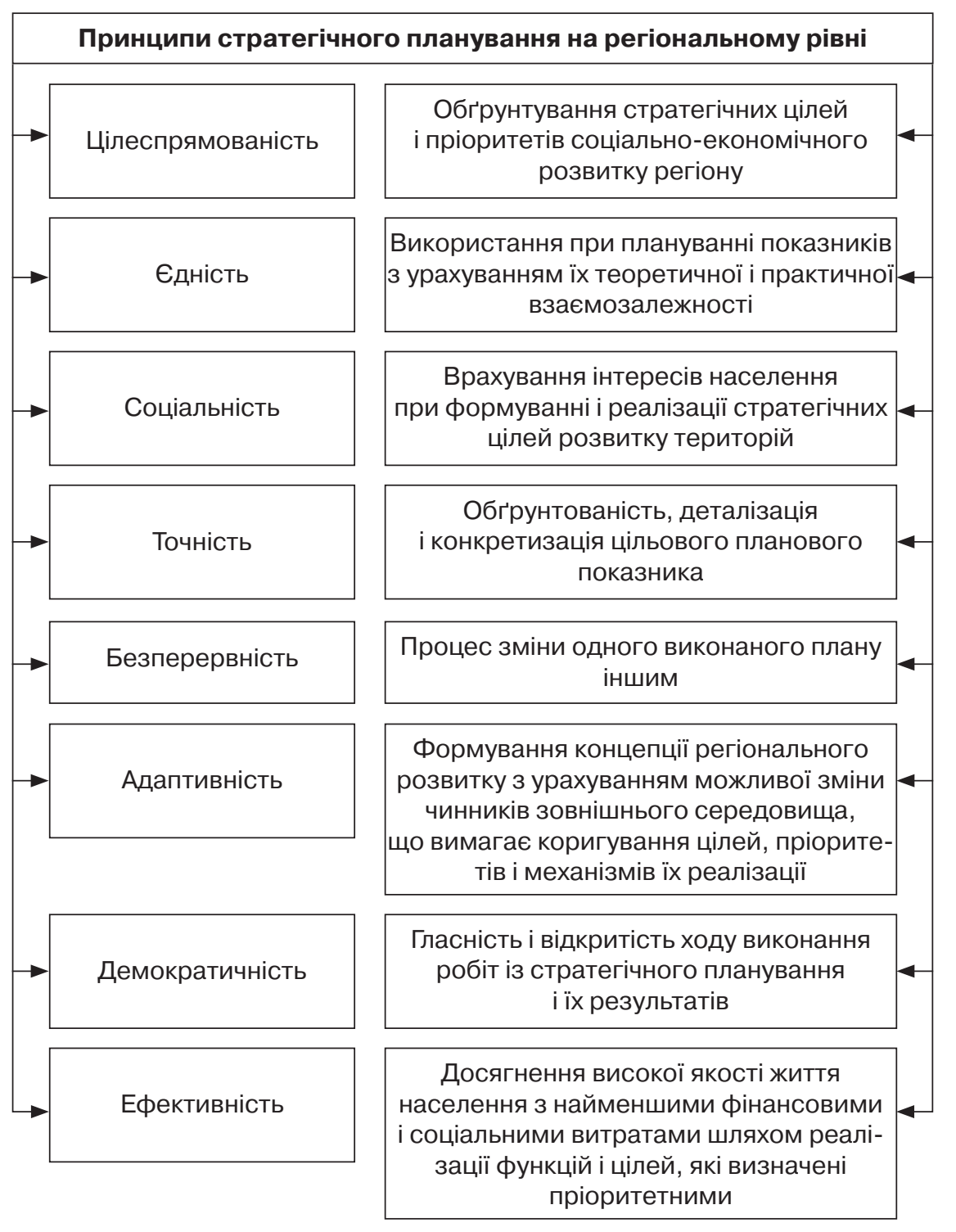

Принципи стратегічного планування на регіональному рівні Джерело: складено автором на основі [6].

регіонального розвитку, планування певних заходів, програм та проектів, які направлені на реалізацію змін задля бажаного майбутнього стану регіону [4, с. 302].

Стратегічне планування передбачає всебічне дослідження ситуації, проведення аналізу зовнішнього се- редовища та внутрішнього потенціалу регіону, вивчення проблем громади, планування бачення розвитку території та оцінки майбутніх стратегічних альтернатив.

Без стратегічного планування не може бути ефективним державне регулювання соціально-економічни- 
ми процесами. Виконання функцій стратегічного планування покладено на органи місцевого самоврядування та органи відповідного рівня, які визначають етапи стратегічного планування та реалізують стратегію регіонального розвитку. Разом з тим, стратегічне планування базується на комунікації між органами державної влади та громадою, тому при плануванні враховуються інтереси сторін, концентруються зусилля та ресурси усіх учасників регіонального розвитку, що сприяє консолідації рішень для їх реалізації. Як зазначають О. Берданова та В. Вакуленко, головним завданням стратегічного планування є забезпечення сталого розвитку територій, проблематика якого посилює необхідність застосування інтегрованого стратегічного підходу до місцевого розвитку [5, с. 6].

На рисунку наведені основні принципи стратегічного планування розвитку територій на регіональному рівні.

Розвиток територій характеризується комплексом просторових, економічних, соціальних, культурнодуховних, екологічних та інших чинників, які повинні враховуватись у процесі стратегічного територіального планування. Тому для територій розробляється не один, а низка планових документів, кожний з яких має свій об'єкт і призначення. У сукупності вони формують цілісну систему планування розвитку територій.

Обов'язковими складовими базових стратегічних планових документів на місцевому рівні є: стратегія місцевого розвитку; просторові програми (генеральні плани населених пунктів); щорічні програми соціаль- но-економічного та культурного розвитку території [7, с. 89].

Серед ключових тенденцій стратегічного планування на регіональному рівні варто віднести:

1. Орієнтація на стратегування розвитку окремих територій (децентралізації в питаннях планування).

2. Орієнтири на досягнення Глобальних цілей сталого розвитку до 2030 року.

3. Застосування підходу SMARTспеціалізації до планування регіонального розвитку. Пошук системоутворюючих галузей та підгалузей регіонального розвитку.

4. Розвиток регіональних кластерних утворень та стимулювання інновацій.

5. Широке залучення стейкхолдерів (громадськості, підприємців) до обговорення проблем розвитку територіï.

6. Встановлення та контроль досягнення ключових КРІ для стратегії розвитку регіону/території.

Розглядаючи розвиток регіону 3 позицій використання його порівняльних переваг, можна сказати, що регіони прискорюють свій розвиток тоді, коли вони використовують свої порівняльні переваги перед іншими регіонами у виробництві товарів та послуг, що користуються попитом. Така спеціалізація на виробництві товарів та послуг отримала назву розумної спеціалізації або SMART-спеціалізації регіону (від smart - розумний). При цьому регіон має можливість не тільки для стимулювання свого розвитку, а й власного впливу на розвиток держави та участь в глобалізаційних процесах. 
Планом 3 реалізації положень Угоди про асоціацію Україна-СС було передбачення впровадження SMART-спеціалізації у систему стратегічного планування регіонального розвитку. На виконання цього плану було передбачено внесення змін до відповідної нормативно-правової бази. Однією з Постанов КMУ [8] SMART-спеціалізація визначається підхід, що передбачає аргументоване визначення суб'єктами регіонального розвитку в рамках регіональної стратегії окремих стратегічних цілей та завдань щодо розвитку видів економічної діяльності, які мають інноваційний потенціал 3 урахуванням конкурентних переваг регіону та сприяють трансформації секторів економіки в більш ефективні, а не менше, ніж одна стратегічна ціль регіональної стратегії має бути визначена на засадах SMART-спеціалізації. Вибір таких пріоритетів повинен відбуватися із урахуванням світових ринкових та технологічних тенденцій інноваційного розвитку та сприяти пошуку тих напрямів економічної діяльності регіону, які є конкурентоспроможними на рівні країни та в міжнародному масштабі.

У вітчизняній практиці при плануванні стратегічного розвитку територій основна увага приділяється розробці Стратегії (документа). Порівняємо традиційний підхід, підхід стратегічного планування та застосування SMART-спеціалізації (табл.).

Першочерговими завданнями стратегічного планування $є$ прискорення економічного зростання територій, підвищення їх конкурентоспроможності на основі ефективного використання внутрішнього потенціалу, збільшення нових робочих місць, покращення зайнятості населення, створення умов для повернення на батьківщину трудових мігрантів. Саме це може дати швидке та стійке зростання рівня якості життя людини незалежно від того, де вона народилась та де вона проживає

Особливості традиційного, стратегічного планування та планування на засадах SMART-спеціалізації

\begin{tabular}{|c|c|c|}
\hline Традиційне планування & Стратегічне планування & $\begin{array}{c}\text { Стратегічне планування } \\
\text { із застосуванням } \\
\text { SMART-спеціалізації }\end{array}$ \\
\hline $\begin{array}{l}\text { Орієнтоване на розробку } \\
\text { Стратегії }\end{array}$ & $\begin{array}{l}\text { Орієнтоване на реалізацію } \\
\text { Стратегії }\end{array}$ & $\begin{array}{l}\text { Орієнтоване на реалізацію } \\
\text { Стратегії та на стимулю- } \\
\text { вання розвитку ключових } \\
\text { галузей }\end{array}$ \\
\hline Технократичний підхід & Партнерський підхід & Партнерський підхід \\
\hline Жорстке впровадження & Гнучке впровадження & Гнучке впровадження \\
\hline $\begin{array}{l}\text { Орієнтація на поточний } \\
\text { стан справ }\end{array}$ & Орієнтація на зміни & $\begin{array}{l}\text { Орієнтація на зміни та си- } \\
\text { нергетичний ефект }\end{array}$ \\
\hline $\begin{array}{l}\text { Моніторинг відповідності } \\
\text { технічним умовам }\end{array}$ & $\begin{array}{l}\text { Моніторинг результатив- } \\
\text { ності }\end{array}$ & $\begin{array}{l}\text { Моніторинг результатив- } \\
\text { ності по ключових КРІ }\end{array}$ \\
\hline $\begin{array}{l}\text { Акцент на Стратегії (доку- } \\
\text { менті) }\end{array}$ & Акцент на Плані реалізації & Акцент на Плані реалізації \\
\hline
\end{tabular}

Джерело: складено автором на основі [6]. 
зараз і де буде проживати у майбутньому [9, с. 25].

Перед органами місцевої влади часто постають питання про недостатність необхідних ресурсів, коли потрібно вирішувати питання щодо пріоритетності сфер виділення коштів: на покращення доріг, на розвиток освіти та медицини, на реконструкцію житлово-комунальної інфраструктури, на підтримку розвитку підприємництва. Щоб не виникало подібних запитань, потрібно правильно скласти Стратегію розвитку територій, визначити пріоритетні цілі, розробити сценарії розвитку територій в існуючих умовах. Для того, щоб скласти та аргументувати План розвитку територій, потрібно виконати складну роботу, пов'язану 3 аналізом усіх внутрішніх та зовнішніх факторів, які впливають на розвиток територій. Але недостатньо лише зібрати інформацію, потрібно з'ясувати конкретні переваги та недоліки і обгрунтувати стратегічний вибір щодо розвитку територій.

Система цілей стратегічного планування місцевого розвитку включає такі елементи: оперативні цілі, які підлягають виконанню впродовж 1-3 років; стратегічні цілі, які реалізуються протягом 3-5 років; пріоритети територіального розвитку в довгостроковій перспективі (10-15 років); підсумки стратегічного бачення розвитку територій (від 10 до 15 років) [10, с. $341 ; 11$, с. 37].

Отже, щоб стратегічне планування розвитку територій стало дієвим інструментом стратегічного управління, потрібно: на основі вивчення потреб окремих територій підготувати якісний стратегічний План розвитку територій, який повинен бути інтегрований у діяльність всіх організаційних структур влади, громадських організацій та місцевого бізнесу; сформувати чітку систему організації процесу розробки стратегічного плану та алгоритм дій, який об'єднує зусилля всіх учасників територіального розвитку.

Реалізація завдань стратегічного планування стає можливою винятково за наявності відлагоджених механізмів взаємодії між центральними органами виконавчої влади та та органами регіонального управління і менеджменту з громадянським суспільством, наукою і бізнесом як необхідної умови підвищення якості життя населення регіонів [12, с. 334].

До реалізації розробленої Стратегії розвитку територій потрібно залучити усі наявні в громаді види капіталу, що дасть змогу сформувати конкурентні переваги окремих територій. Важливою умовою ефективності стратегічного планування виступає: реалістичність визначених цілей; грунтовний моніторинг соціально-економічного становища регіону (території); орієнтація на інноваційність стратегії; оптимальний вибір галузей SMART-спеціалізації

Висновки. Стратегічне планування розвитку територій є складовою системи стратегічного управління їх соціально-економічним розвитком і полягає у визначенні напрямів та шляхів досягнення бажаного стану об’єктів управління, реалізація, яких забезпечує їх ефективне функціонування у довгостроковій перспективі та швидку адаптацію до особливостей зовнішнього середовища. Сучасний етап планування терито- 
ріального розвитку в Україні характеризується тенденцією переходу від традиційного до планування з орієнтацією на забезпечення сталого розвитку. Актуальним стає поширена в державах EC SMART-спеціалізація регіонального розвитку, яка також почала застосовуватись в Україні при розробці стратегій.

Реалізація інструментів стратегічного планування сприяє розвитку різних форм співробітництва та кооперації з бізнес-структурами регіону і є підставою для деталізованого планування розвитку територій, розвитку кластерів економіки.

\section{СПИСОК ВИКОРИСТАНОÏ ЛІТЕРАТУРИ}

1. Державна стратегія регіонального розвитку на 2021-2027 роки. URL: https://www.kmu.gov.ua/npas/ pro-zatverdzhennya-derzhavnoyistrategiyi-regionalnogo-rozvitku-na20212027-t50820

2. Рогатіна Л. П. Стратегічне управління економічним розвитком, його особливості та роль у формуванні конкурентних переваг регіону // Економіка та держава. 2018. № 2. C. 92-96.

3. Бурик 3. М. Державне регулювання сталого розвитку України: теорія та практика: монографія. Львів: Простір-М, 2017. 384 c.

4. Пуцентейло П. Р., Завитій О. П. Особливості формування стратегії управління економічним розвитком регіону // Подільський вісн.: сільське господарство, техніка, економіка. 2017. № 27. С. 298-308.

5. Берданова О., Вакуленко В. Стратегічне планування місцевого розвитку : практ. посіб. Швейцар.-укр. проект "Підтримка децентралізації в Україні - DESPRO”. К. : София-А, 2012.88 c.

6. Моніторинг процесу децентралізації влади та реформування місцевого самоврядування: станом на 10 листопада 2019 р. / Міністерство розвитку громад та територій України. Київ, 2019. 31 с. URL : https://decentralization.gov.ua/ uploads/library/file/494/10.11.2019. pdf

7. Бриль М., Врублевський О., Данчева О. Успішна територіальна громада: будуємо разом. Харків: Фактор, 2018. 128 c.

8. Угода про асоціацію між Україною та Європейським Союзом. URL : http://www.kmu.gov.ua/control/uk/ publish/article?art_id=246581344.

9. Кіш Г. В. Стратегічне планування як інструмент управління національної економіки // Наук. вісн. Ужгород. ун-ту. 2015. Вип. 1 (45). Т. 3. С. $73-$ 77.

10. Тертичка B. В. Стратегічне управління: підручник. Київ: К.І.С., 2017. $932 \mathrm{c}$

11. Зуб Д. С. Стратегічне планування: вітчизняна практика та напрями вдосконалення // Формування ринкових відносин в Україні. 2012. Вип. 1. С. 36-40.

12. Варцаба В. I. Управління регіональним розвитком: теорія і практика гармонізації цілей та інтересів влади, науки, бізнесу : монографія. Івано-Франківськ : ІФНТУНГ, 2015. $486 \mathrm{c}$.

\section{REFERENCES}

1. Postanova Kabinetu Ministriv Ukrayiny Pro Zatverdzhennia Derzhavnoi Stratehii Rehionalnoho Rozvytku Na 2021-2027 Roky: pryiniata 5 August 2020 roku № 695. [Resolution of the Cabinet Of Ministers of Ukraine On approval of the State Strategy for Re- 
gional Development for 2021-2027, August 5, 2020 № 695] Retrieved from https://www.kmu.gov.ua/npas/ pro-zatverdzhennya-derzhavnoyistrategiyi-regionalnogo-rozvitku-na20212027-t50820 [in Ukrainian].

2. Rohatina L. P. (2018). Stratehichne upravlinnia ekonomichnym rozvytkom, yoho osoblyvosti ta rol u formuvanni konkurentnykh perevah rehionu [Strategic management of economic development, its features and role in the formation of competitive advantages of the region]. Ekonomika ta derzhava - Economy and state, 2, 92-96 [in Ukrainian].

3. Buryk Z. M. (2017). Derzhavne rehuliuvannia staloho rozvytku Ukrainy: teoriia ta praktyka [State regulation of sustainable development of Ukraine: theory and practice]. L'viv: Vyd-vo Prostir M [in Ukrainian].

4. Putsentejlo P. R., Zavytij O. P. (2017). Osoblyvosti formuvannia stratehii upravlinnia ekonomichnym rozvytkom rehionu [Features of formation of strategy of management of economic development of region]. Podil's'kyj visnyk: sil's'ke hospodarstvo, tekhnika, ekonomika - Podilsky Bulletin: agriculture, technology, economics, 27, 298308 [in Ukrainian].

5. Berdanova O. \& Vakulenko V. (2012). Stratehichne planuvannia mistsevoho rozvytku [Strategic planning of local development]. Kyiv: Sofyia-A [in Ukrainian].

6. Monitorynh protsesu detsentralizatsii vlady ta reformuvannia mistsevoho samovriaduvannia: Ministerstvo Rozoytku Hromad Ta Terytorii Ukrainy [Monitoring the process of decentralization of power and reform of local self-government: Ministry of Development of Communities and Territories of Ukraine] (2019) Retrieved from https://decentralization.gov.ua/up- loads/library/file/494/10.11.2019.pdf [in Ukrainian].

7. Bryl' M., Vrublevs'kyj O., Dancheva O. (2018). Uspishna terytorial'na hromada: buduiemo razom [Successful territorial community: we build togeth$e r$ ]. Kharkiv: Faktor [in Ukrainian].

8. Uhoda pro asotsiatsiyu mizh Ukrainoiu z odniiei storony ta Yeoropeiskym Soiuzom yevropeiskym spivtovarystvom z atomnoi enerhii i yikhnimy derzhavamychlenamy $z$ inshoi storony [Association Agreement between the European Union and the European Atomic Energy Community and their member states, of the one part, and Ukraine, of the other part] Retrieved from http://www.kmu.gov. ua/control/uk/publish/article?art id $=246581344$ [in Ukrainian].

9. Kish H. V. (2015). Stratehichne planuvannia yak instrument upravlinnia natsionalnoi ekonomiky [Strategic planning as a tool for managing the national economy]. Naukovyi Visnyk Uzhhorodskoho Universytetu - Scientific Bulletin of Uzhhorod University, 1, 73-77.

10. Tertychka V. V. (2017). Stratehichne upravlinnia [Strategic management]. Kyiv: K.I.S [in Ukrainian].

11. Zub D. S. (2012). Stratehichne planuvannia: vitchyzniana praktyka ta napriamy vdoskonalennia [Strategic planning: domestic practice and areas for improvement]. Formuvannia rynkovykh vidnosyn v Ukraini - Formation of market relations in Ukraine, 1, 36-40 [in Ukrainian].

12. Vartsaba V. I. (2015). Upravlinnia rehional'nym rozvytkom: teoriia i praktyka harmonizatsii tsilej ta interesiv vlady, nauky, biznesu [Regional development management: theory and practice of harmonization of goals and interests of government, science, business]. Ivano-Frankivs'k: IFNTUNH [in Ukrainian]. 